\title{
Letter from the LFKS to the Public 李方桂學會致讀者的公開信
}

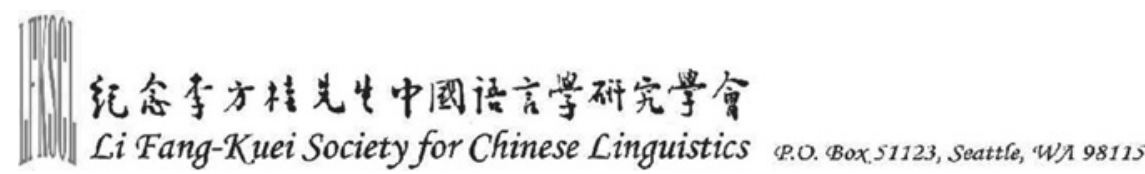

May 2006

Dear Mr. /Ms. 先生/女士:

Chinese linguistics in the United States began with the work of Chao Yuen Ren and Li Fang-Kuei; Professor Chao taught at the University of California at Berkeley, Professor Li at the University of Washington in Seattle. Each of them established a magnificent tradition. Now that the Chao Yuen Ren Center for Chinese Linguistics has come to an end at Berkeley, that tradition has been interrupted. A group of scholars who are concerned about the legacy of Chao and Li and who have links to Professor Chao and Professor Li, with Anne Yue-Hashimoto taking the initiative, wish to establish a "Li Fang-Kuei Society for Chinese Linguistics" as a permanent memorial to Professor Li's contributions to Chinese linguistics and in order to promote the development of Chinese linguistics.

中國語言學在美國的發展從趙元任、李方桂兩位先生開始, 趙先生在柏克萊加州 大學, 李先生在西雅圖華盛頓大學, 各自建立了光輝的傳統。自從柏克萊的趙元任中 心停辦以後, 這個傳統已經無以為繼。一群關心中國語言學發展並和兩位先生都有密 切關聯的學者, 為了繼承趙李兩位先生的衣砵, 在余靄芹的發起之下, 成立了一個 $\ulcorner$ 紀念李方桂先生中國語言學研究學會」，永久紀念李先生對中國語言學的貢獻，並 推動中國語言學的發展。

The field of linguistics has given Professor Li the title of "father of non-Han linguistics in China" to match Professor Chao's title of "father of Chinese linguistics." Professor Li's contributions to linguistics are many-faceted: he was an authority on Athabascan languages and Sino-Tibetan linguistics and is one of the founders of modern linguistics in China, and, perhaps most importantly, he was the founder of comparative Tai linguistics. These various fields are all closely related to the study of the Chinese, Athabascan being no exception; therefore a "Society for the Study of Chinese Linguistics" is a most appropriate way to commemorate Professor Li.

語言學界給李方桂先生的尊稱是：「非漢語」語言學之父，和趙元任先生的「漢語語言 學之父」交相輝映。李先生對語言學的貢獻是多方面的, 他是研究印第安語 Athabaskan 和漢 藏語的權威, 是中國語言學的開山祖師之一, 更是侗台語比較研究的創始者。這些語言的研究 都和中國語言有密切的關係, 印第安語 Athabaskan 也不例外, 所以用「中國語言學研究學會」 的名義來紀念李方桂先生是最合適不過的。 
The Society has now been formed and registered as a non-profit organization in the state of Washington, U.S.A. on October 1, 2003. The Li Fang-Kuei Society for Chinese Linguistics includes the following members:

現在學會已經組成，並於二零零三年十月一日在美國華盛頓州正式登記為非營利機構。「紀 念李方桂先生中國語言學研究學會」包括以下成員:

President 會長: Ting Pang-Hsin 丁邦新, Agassiz Professor Emeritus of Chinese, University of California at Berkeley, former dean of the School of Humanities and Social Science, Hong Kong University of Science and Technology 前柏克萊加州大學中國語言學 Agassiz 講座教授, 前香港科技大學人文社 會科學學院院長

Secretary/Treasurer 秘書兼司庫: Anne Yue-Hashimoto 余霰芹, professor, Department of Asian Languages and Literature, University of Washington, Seattle 華盛頓大學亞洲語文系教授

Deputy Secretary/Treasurer 副秘書兼財務: Zhongwei Shen 沈鍾偉, professor, University of Massachusetts at Amherst 安默斯特麻州大學教授

Directors 董事: Hung-Nin Samuel Cheung 張洪年, professor emeritus, University of California at Berkeley, chair professor, Chinese University of Hong Kong, 前柏克萊加州大學教授，香港中文大學 中文系講座教授; South W. Coblin 柯蔚南, professor, University of Iowa, 愛我華大學亞洲語文系教授; C.-T. James Huang 黃正德, professor of linguistics, Harvard University, 哈佛大學語言學系教授; Tsu-Lin Mei 梅祖麟, Hu Shih Professor Emeritus of Chinese, Cornell University, 前康奈爾大學亞洲研究系胡適講 座教授; Ken-ichi Takashima 高嶋謙一, professor emeritus, University of British Columbia, 前英屬哥倫比 亞大學亞洲研究系教授; Pang-Hsin Ting 丁邦新; Anne Yue-Hashimoto 余霭芹

Advisory Committee 顧問: [chairs主席] Jerry Norman 羅杰瑞, professor emeritus, Department of Asian Languages and Literature, University of Washington, 前華盛頓大學亞洲語文系教授; C.-T. James Huang 黃正德

Development Committee 籌劃委員會: [chair 主席] Mei Tsu-Lin 梅祖麟; [deputy chairs 副主席] Dah-An Ho 何大安, director cum research fellow, Institute of Linguistics, Academia Sinica, 中央研究院 語言研究所所長兼研究員; Chaofen Sun 孫朝奮, professor, Department of Asian Studies, Stanford University, 斯坦福大學亞洲研究系教授

Publication Committee出版委員會: [chair 主席] Hung-Nin Samuel Cheung 張洪年, Dah-An Ho何大 安, Anne Yue-Hashimoto 余靄芹, Min Zhang張敏, professor, Hong Kong University of Science and Technology, 香港科技大學

The development of Chinese linguistics in the United States is closely related to Chinese language teaching. Almost everyone who works in Chinese linguistics also teaches Chinese; the study of Chinese phonology, grammar and vocabulary is also linked to language teaching. A student must first master Chinese before s/he can go on to the study of culture, literature, history or philosophy. It is no exaggeration to say that Chinese linguistics is inseparable from the development of American sinology. For these reasons, we should all vigorously promote the study of Chinese linguistics. In this sense, then, the establishment of the "Li Fang-Kuei Society for Chinese Linguistics" is not only for the remembrance of Professor Li Fang-Kuei but also for the furtherance of the field to which he dedicated his life.

中國語言學在美國的發展和漢語教學有密切的關聯, 從事中國語言學研究的人幾乎都教漢 語, 漢語的音韻、文法、詞彙的研究都跟語言教學息息相關。學生能掌握漢語才能進一步研究 中國的文化、文學、歷史、哲學等等。如果說得強調一點, 中國語言學的研究和美國漢學的發 展有密不可分的關係, 應該不是過分的話。既然如此, 我們更應該大力提倡中國語言學的研 
究。在這一層意義上, 「紀念李方桂先生中國語言學研究學會」的成立就不止是紀念李方桂先 生而已。

Our most important task at present is fund raising. In four year's time the members of the Li Fang-Kuei Society for Chinese Linguistics have contributed almost $\$ 180,000$. None of these people is rich; they have willingly contributed from their meager resources to express their respect for Professor Li and their support for setting up this Society. We are writing this letter to Professor Li's friends, students, his students' students, to distinguished members of society and those who are concerned about the future of Chinese linguistics. We hope that all of you will be able to make a contribution for this Society.

現在最重要的工作就是要募捐, 在短短的四年內, 「紀念李方桂先生中國語言學研究學 會」的成員已經捐獻了接近十八萬美元。這些成員都不是富裕的人, 樂意捐助只是盡棉薄之力 表達對李先生的敬意, 對建立這個學會的支持。現在我們寫這封信給李方桂先生的朋友、學 生、學生的學生、不認識李先生的社會賢達、關心中國語言學前途的人, 希望諸位為紀念李方 桂先生也為中國語言學的發展慷慨解囊。

We wish you good health and good luck.

在這新的一年裡, 希望您一切順利, 也希望「紀念李方桂先生中國語言學研究學會」能夠 得到您的支持。敬祝

康健逾恆, 心想事成

Yours sincerely,

Ting Pang-Hsin 丁邦新, Anne Yue-Hashimoto 余䨠芹, Hung-Nin Samuel Cheung 張洪年, South Coblin 柯蔚南, C.-T. James Huang 黃正德, Mei Tsu-Lin 梅祖麟, Ken-ichi Takashima 高嶋謙一, Jerry Norman 羅杰瑞, Ho Dah-An 何大安, Sun Chaofen 孫朝奮, Shen Zhongwei 沈鍾偉, Zhang Min 張敏

Please send your donation to 捐款請寄下列「紀念李方桂先生中國語言學研究學會」會址:

Li Fang-Kuei Society for Chinese Linguistics

P.O. Box 51123, Seattle, WA $98115^{-1123}$, U.S.A. 